\title{
A felsőoktatás és a szabad mozgáshoz való jog az Európai Unió Bíróságának ítélkezési gyakorlatában
}

\author{
szabad mozgáshoz való jog - felsőoktatás - Európai Bíróság esetjoga - \\ európai polgárság
}

A 20. század második fele és a 21. század eleje meghatározó jelentőséggel bírt az egyes államok felsőoktatási rendszerének formálódásában, illetve az európai egyetemek mai arculatának kialakulásában. Egymással párhuzamosan jelentkező hatások, háttérfolyamatok eredményeként a hagyományosan nemzetállami szinten szabályozott felsőoktatás egyfajta „európaizálódásának” folyamata zajlik; mindeközben pedig az európai egyetemek tevékenysége mind tartalmilag, mind szervezési kereteit tekintve átalakul.

Amikor a felsőoktatás európai szintű vívmányaira gondolunk, magától értetődően a bolognai folyamat jut először eszünkbe. Az Unió hozzájárulása is jelentős részben erre építkezik, ugyanakkor túl is terjed a bolognai célokhoz rendelt uniós jogi eszközök megalkotásán. Figyelembe véve az integráció alapvető céljait és értékeit, a belső piac müködésének sajátos logikáját, egyértelmüen azt mondhatjuk, hogy az Unió felsőoktatást érintő intézkedéseinek sajátos prioritásai és eredményei vannak.

Jelen írás vizsgálódásának középpontjában az Európai Unió Bíróságának (a továbbiakban: Bíróság) ítélkezési gyakorlata áll. A felsőoktatással kapcsolatos uniós célkitűzések megvalósítása szempontjából meghatározó szerepe van az ítélkezési gyakorlatban kidolgozott jogelveknek - leginkább a diszkrimináció tilalmával, illetve a munkavállalókat, uniós polgárokat megillető, szabad mozgáshoz való jog tartalmával kapcsolatos döntéseknek. A Bíróságnak fontos közvetítő szerepe van a különböző uniós szakpolitikák, illetve ezek megvalósításához juttatott uniós szabályozási hatáskörök között, és ennek különösen jó példája a szabad mozgáshoz való jog és az uniós oktatási politika közötti - nem explicite elismert, de mégis jól érzékelhető - interakció alakulása. Elsősorban arra keressük a választ, hogy az ítélkezési gyakorlat miként segíti elő a bolognai folyamat, illetve az Unió oktatási politikájának

* Dr. Bartha Ildikó egyetemi adjunktus, Debreceni Egyetem Állam- és Jogtudományi Kar Európa-jogi és Nemzetközi Jogi Tanszék, MTA-DE Közszolgáltatási Kutatócsoport, bartha.ildiko@law.unideb.hu. A tanulmány a Magyar Tudományos Akadémia és a Debreceni Egyetem Állam- és Jogtudományi Kar közös, MTA-DE Közszolgáltatási Kutatócsoportjának a Területi közszolgáltatások szabályozásai című projektje keretében készült. A projekt leírására lásd: HoRVÁTH M. Tamás: Szempontok a területi közszolgáltatások regulációs változásainak vizsgálatához. In: Horváth M. Tamás (szerk.): Kilengések. Közszolgáltatási változások. Dialóg Campus, Budapest, 2013, 9-25. 
a hallgatói mobilitás ösztönzésével kapcsolatos célkitűzéseit, és milyen sajátos kihívásokat produkál.

Fontos hangsúlyoznunk, hogy a Bíróság vizsgált esetjogának korábbi szakasza időben egybeesett az európai felsőoktatás legnagyobb horderejünek tartott, a 20. század második felére tehető átalakulásával, amelyet a hallgatói létszámexpanzió, az oktatás tömegessé válása jellemez. A felsőoktatás a társadalmi elit privilégiumából szolgáltatássá vált, a „fogyasztók” szempontjai prioritást nyertek, így a hallgatók pozíciója is gyökeresen megváltozott, és az új típusú feladatoknak megfelelően átalakult az intézmények menedzselésének a modellje is. Az állam szerepe megerösödött a nagy növekedés első szakaszában (amely nagyjából a 60 -as évek elejétől a 70-es évek végéig tartott), majd pedig bizonyos értelemben véve háttérbe szorult, teret engedve a piacért, a hallgatókért és a kutatási erőforrásokért folyó versenynek. A 2008-ban kezdődött gazdasági és pénzügyi válság újabb fordulatokat hozott a felsőoktatás terén: a legtöbb európai országban az állam kontrollszerepét erősítő eszközök megjelenését, de egyúttal a központi költségvetési kiadások csökkentését is eredményezte, párhuzamosan a magánforrások bevonását ösztönző oktatáspolitikai intézkedésekkel. ${ }^{1} \mathrm{E}$ folyamatokkal is (hol szorosabb, hol lazább) összefüggésbe hozhatók az ítélkezési gyakorlat jelentősebb állomásai, irányváltásai. ${ }^{2}$

\section{Az Európai Unió felsőoktatási politikájának alapjai}

Az Európai Gazdasági Közösséget alapító szerződés eredetileg nem rendelkezett önálló közösségi oktatási politikáról, formális alapot ennek csak az 1993-ban hatályba lépett Maastrichti Szerződés teremtett. Az Európai Közösség keretében ugyanakkor már ezt megelőzően születtek olyan uniós szintű vívmányok, amelyek hatása a tagállami felsőoktatási rendszerek közeledését eredményezte.

E korai eredmények jelentős részben a Közösség (Unió) legeredetibb célkitűzésének számító közös piac koncepciójához, illetve az (ennek részét képező) egyes gazdasági alapszabadságokhoz kötődtek. Már az 1958-ban hatályba lépett EGK Szerződés ${ }^{3}$ felhatalmazást adott a Tanácsnak arra, hogy megállapítsa egy közös szakképzési politika általános elveit, amely „a közös piac harmonikus fejlödéséhez képes hozzájárulni”. ${ }^{4}$

A szakképzésen túli területeket nézve már egy 1974-es tanácsi ajánlás ${ }^{5}$ megfogalmazta, hogy a tagállamok oktatási politikájának segítenie kell a letelepedés és a

1 Vesd össze KovÁTs Gergely: A felsőoktatás autonómiája a 2010 és 2013 közötti felsőoktatás-politika tükrében. In: Hrubos Ildikó (szerk.): Autonómiák a felsőoktatásban. Mühelytanulmányok. BCE Közgazdaságtudományi Kar NFKK, Budapest, 2013, 54.

2 HRuBos Ildikó: Az akadémiai professzió - változó pozícióban. Educatio, 2007/3, 353-365.

3 Az Európai Gazdasági Közösséget (később Európai Közösség, majd Európai Unió) létrehozó, 1958. január 1-jén hatályba lépett szerződés.

4 EGK Szerződés 128. cikk, jelenleg az EUMSZ 165. cikke. A fent említett általános elvek lefektetését a Tanács már az európai integráció korai éveiben megkezdte, lásd különösen a Tanács határozatát (1963. április 2.) a közös szakképzési politika megvalósítása általános elveinek megállapításáról, HL L 63, 1963. 04. 20., 1338.

5 Tanácsi ajánlás, 1974. június 6. 
szolgáltatások szabad mozgásának a megvalósítását. A diplomák és képesítések kölcsönös elismerése hozzájárulhat ugyanis e két gazdasági alapszabadság kiteljesedéséhez. A Tanács ezt követően bocsátotta ki a különböző képzési területeken a képesítések elismeréséröl szóló ún. szektorális irányelveket, ${ }^{6}$ majd 1988-ban a legalább hároméves szakoktatást és szakképzést lezáró felsőfokú oklevelek elismerésének általános rendszeréről szóló irányelvét. ${ }^{7} \mathrm{E}$ jogi aktusok érezhetően arra inspirálták a tagállamokat, hogy vizsgálják a más tagállamok oktatási rendszerét is és vessék össze a sajátjukkal. A 89/48/EGK irányelv mindemellett egyfajta szabályozási versenyt is megindított a tagállamokban. Azzal ugyanis, hogy rögzítette a - hároméves képzési időszakot tanúsító - felsőfokú oklevelek elismerésének általános rendszerét, egyúttal olyan üzenetet is közvetített, hogy a hosszú időtartamú képzések nem versenyképesek uniós szinten. ${ }^{8}$

A szolgáltatás, a letelepedés, illetve a munkavállalás szabadságához kötődik a Bíróság „felsőoktatási esetjogának” legelső, Gravier-itélete is. Az alapügyben felperes francia állampolgárnak a belga előírások szerint beiratkozási díjat kellett fizetnie azért, hogy részt vehessen Liège város művészeti akadémiájának képzésén. A Bíróság megállapította, hogy a más tagállamok föiskolai hallgatóira kivetett beiratkozási díj - amely a képzésben való részvétel előfeltétele és amely alól a hazaiak mentesültek -, állampolgársági alapon történő diszkriminációnak minősül. ${ }^{9}$

A Gravier-ítéletben a Bíróság első alkalommal terjesztette ki az egyenlő elbánás elvét a felsőoktatás területére. A döntés értelmében tehát valamely uniós tagállam állampolgárságával rendelkező hallgatók ugyanazon feltételek mellett vehetnek részt egy másik tagállam felsőoktatási intézményének képzésében, mint e fogadó állam állampolgárai. Emellett az ítélet egyértelmüvé tette, hogy e területre kiterjed az Unió hatásköre, mivel a felsőoktatás egy meghatározott szakmára készít fel, és így a letelepedés, a szolgáltatásnyújtás és munkavállalás szabadságát elősegíteni célzó, az EGK Szerződés 128. cikke ${ }^{10}$ szerinti „szakképzés” fogalomkörébe tartozik. ${ }^{11} \mathrm{Ez}$ utóbbi következtetés összhangban van azzal az - Európában már a 60-as években megkezdődő - tendenciával, hogy az egyetemekkel szemben fokozatosan

6 Lásd többek között az általános orvosokra vonatkozóan a 76/362/EGK (1975. június 16.; HL L 167, 1975. 06. 30., 1-13.), 76/363/EGK (1986. szeptember 15.; HL L 167, 1975. 06. 30., 14-16.) és 86/457/EGK (1975. június 16.; HL L 267, 1986. 09. 19., 26-29.) irányelvet, valamint az ezeket felváltó 93/16/EGK irányelvet (1993. április 5.; HL L 165, 1993. 07. 07., 1-24.); az építészekre a 85/384/EGK irányelvet (1985. június 10.; HL L 223, 1985. 08. 21., 15-25.); a fogorvosokra a 78/868/EGK irányelvet (1985. június 10.; HL L 223, 1985. 10. 09., 26-27.).

7 A Tanács 89/48/EGK irányelve (1988. december 21.), HL L 19, 1989. 01. 24., 16-23.

8 HACKL, Elsa: Towards a European Area of Higher Education: Change and Convergence in European Higher Education. EUI Working Paper, 2001/09, 9.

9 C-293/83. sz., Gravier-ügyben hozott ítélet (ECLI:EU:C:1985:69).

10 Lásd a 4. lábjegyzetet.

11 C-293/83. sz., Gravier-ügyben hozott ítélet, 30. pont: „szakképzés a képzés minden olyan formája, amely felkészít egy meghatározott szakmára vagy egy meghatározott foglalkozásra vonatkozó képzettség megszerzésére, vagy amely különösen alkalmassá tesz ilyen szakma vagy ilyen foglalkozás végzésére". E megállapítást a Bíróság megerősítette később a 24/86. sz., Blaizot kontra Université de Liège és társai (ECLI:EU:C:1988:43), valamint a 242/87. sz., Bizottság kontra Tanács (ERASMUS) (ECLI:EU:C:1989:217) itéleteiben is. 
erősödik a gazdaságilag értékes munkaerő „termelése” mint társadalmi elvárás. Az európai felsőoktatás tantervének, tananyagának, a felkínált képzések tartalmának alakulásában az akadémiai és professzionális orientációtól az ipar és a munkáltatói szektor igényei felé történő elmozdulás látható. A teoretikus jellegü, akadémiai képzések helyett tehát valóban a szakképzés-orientált kurzusok kerülnek előtérbe, és az egyetemek missziójában egyre inkább az emberi erőforrás termelése dominál. ${ }^{12}$

Egyes szerzők szerint az ítélet közvetlen elözménye volt az Erasmus-programot elindító tanácsi határozatnak is. ${ }^{13} \mathrm{~A}$ ma már széles körben ismert program célja, hogy a különböző országok felsőoktatási intézményei között együttmüködési hálózatot hozzon létre és támogatást nyújtson olyan hallgatóknak, akik tanulmányaik egy részét egy másik tagállam egyetemén kívánják folytatni. A mobilizáció e szervezett formába öntését eredetileg az ellenőrizetlen és egyenetlenül eloszló migráció megelőzésének érdeke ösztönözte. Az Erasmus-programok szintén hatással voltak a tagállamok oktatási rendszerére, és az érintett egyetemeken közös képzési programok indítását is inspirálták. ${ }^{14}$

A korai ítélkezési gyakorlatból az is kiderül, hogy a tagállami oktatási autonómiát az uniós belső piaci szabályok nem egyformán érintik a felsőoktatás, valamint az alap- és középfokú oktatás terén. A Blaizot-ítélet értelmében az egyetemi tanulmányok megfelelnek a Gravier-itélet szerinti „szakképzés” követelményének, ${ }^{15}$ csak egészen kivételes, egyedi jellegü képzések esetében lehet ez alól kivételt tenni. ${ }^{16}$ A szakképzésekre pedig kiterjed a munkavállalók szabad mozgásának elve annak minden következményével, függetlenül attól, hogy a képzést állami felsőoktatási intézmény vagy magánegyetem végzi. Az állami egyetemek tehát - amelyek az európai felsőoktatási intézmények megközelítőleg 95\%-át teszik ki - nem mentesülnek az uniós szabályok alkalmazása alól pusztán amiatt, hogy az állami fenntartó által finanszírozott közfeladatot látnak el. Az alap- és középfokú oktatás esetében viszont a Bíróság már megszorítóbban értelmezi a „szakképzés” fogalmát, ugyanakkor azt is világossá tette, hogy a - szakképzésnek nem minősülö - szakközépiskolai képzés nem minősül szolgáltatásnak a (jelenlegi) EUMSZ 59. cikke értelmében, amenynyiben az állam által finanszírozott és felügyelt nemzeti oktatási rendszer keretében megszervezett közoktatás részét képezi, akkor sem, ha a költségek fedezéséhez kisebb részben a diákok, illetve a szülök által fizetett tandíj is hozzájárul. Szolgáltatásnak tehát csak az alapvetően magánforrásokból finanszírozott képzések tekinthetők. ${ }^{17}$

12 HACKL: i. m., 3-5.

13 SHAw, Jo: From the Margins to the Centre: Education and Training Law and Policy. In: Craig, Paul-de Búrca, Grainne (eds.): The Evolution of EU Law. Oxford University Press, Oxford, 1999, 264; HACKL: i. m., 11.

14 HACKL: i. m., 12-13.

15 Lásd a 11. lábjegyzetet.

16 24/86. sz., Blaizot-ügyben hozott ítélet (ECLI:EU:C:1988:43), 15. pont.

17 263/86. sz., Humbel és Edel-ügyben hozott ítélet (ECLI:EU:C:1988:451), 18. pont. 


\section{A szakképzésen túl... - Az Unió önálló oktatási politikája és az uniós polgár felsőoktatáshoz való joga}

Az állam szerepének megváltozása, valamint az egyetemekkel szemben továbbra is erősödő „gazdasági hatékonysági” elvárás legitimációs alapot teremtett az Unió új felsőoktatási politikájához, illetve egyéb, európai szinten szerveződött együttmüködési formákhoz (elsősorban a bolognai folyamathoz) is.

Az Európai Uniót létrehozó, 1993-ban hatályba lépett Maastrichti Szerződés fektette le az Unió önálló oktatási politikájának alapjait. ${ }^{18} \mathrm{Az}$ integráció ezen új területének életre hívása része volt egy olyan átfogó folyamatnak, amely a gazdasági integráción túllépő, szorosabb európai egység megteremtésére irányult. İgy az európai szinten szervezett felsőoktatási programok sem csupán az egységes belső piac elmélyítésének lehettek hatékony eszközei, hanem annak is, hogy a tagállamok állampolgárai - szemléletüket tekintve is - valódi uniós polgárokká váljanak.

E körülmények közvetlen előzményei voltak a bolognai folyamatot elindító, 1998-as sorbonne-i nyilatkozat elfogadásának is. ${ }^{19} \mathrm{~A}$ bolognai folyamat vívmányai az aláíró államok európai uniós kereteken kívül létrejött kormányközi együttműködésének eredményei, önkéntes kötelezettségvállalások saját oktatási rendszerük megreformálására és egy Európai Felsőoktatási Térség (EFT) megteremtésére. Jogilag tehát nem kötik sem a nemzeti kormányokat, sem a felsőoktatási intézményeket. ${ }^{20} \mathrm{Az}$ együttmüködés keretében megfogalmazott célkitüzések részét képezi, hogy meg kell szüntetni a hallgatók, az oktatók és a kutatók mobilitásának minden akadályát. ${ }^{21}$ A bolognai folyamat, valamint az uniós keretek között elért eredményeknek köszönhetően - a képzési struktúra átalakulásán túl - a más tagállamban felsőoktatási intézményt látogató diákok száma tovább növekszik (2011-es adatok szerint a 2000-es számokhoz képest több mint 50\%-kal'22).

Visszatérve az uniós alapokhoz, a Maastrichti Szerződéssel bevezetett felhatalmazás szerint az Unió csupán támogató, kiegészítő hatáskörrel${ }^{23}$ rendelkezik az

18 Jelenleg az EUMSZ 165. cikke.

19 HACKL: i. m., 16.

20 A részt vevő országok oktatásért felelős miniszterei a bolognai nyilatkozat aláírása óta minden második évben találkozót (ún. follow-up üléseket) tartanak a folyamat előrehaladásának értékelése és a további cselekvési prioritások meghatározása érdekében (lényegében e találkozókat, illetve az általuk beindított aktivitásokat együttvéve nevezzük „,bolognai folyamatnak”).

21 Bolognai Nyilatkozat - Az európai felsőoktatási térség Európa oktatási minisztereinek közös nyilatkozata (Bologna, 1999. június 19.), elérhető: http://www.aic.Iv/ace/ace_disk/Bologna/maindoc/bologna_declaration. pdf. A nyilatkozat a részt vevő országok hat fő célkitűzését rögzíti, amelyek - kiegészítve a késői találkozók eredményeivel - összefoglalva az alábbiak: (1) meg kell teremteni az összehasonlítható felsőoktatási képzések, illetve e képzések elismerésének rendszerét és (2) egy alapvetően három képzési cikluson (bachelor - master - doktori) alapuló képzési rendszert; (3) egy kreditátviteli és -gyűjtési rendszert az ECTS- (European Credit Transfer and Accumulation System) modell alapján, melyet az Erasmus-csereprogram használ; (4) meg kell szüntetni a hallgatók, az oktatók és a kutatók mobilitásának minden akadályát; (5) ki kell építeni egy európai szintű minőségbiztosítási rendszert; (6) növeli azon modulok, oktatási és tanulmányi területek számát, amelyek tartalmában, irányában vagy szervezésében megmutatkozik az európai dimenzió.

22 Commission Staff Working Document SEC. Progress Towards the Common European Objectives in Education and Training (2010/2011): Indicators and Benchmarks, 2011, 33-40.

23 EUMSZ 6. cikke szerinti hatáskör-osztályozás. 
oktatás szabályozása terén és intézkedései nem irányulhatnak a tagállami jogrendszerek harmonizációjára. ${ }^{24} \mathrm{Az}$ Unió hatáskörének terjedelme e téren a későbbi szerződésmódosításokkal sem bővült, az uniós „felsőoktatási vívmányok” jelenleg is alapvetően az ún. „nyitott koordinációs módszer” (Open Method of Coordination, $O M C$ ) keretében valósulnak meg. ${ }^{25}$ Fontos viszont megjegyeznünk, hogy az uniós polgárság intézményét - a szorosabb integrációra törekvés jegyében - szintén a Maastrichti Szerződés tette az európai integráció részévé. A felsőoktatáshoz való hozzáféréssel kapcsolatos esetek tehát azért is jelentősek, mert általuk (a tagállami oktatáspolitikai hatáskörök határainak értelmezésén túl) egyben arra is alkalma nyílt a Bíróságnak, hogy az uniós polgár státusz lényegét és rendeltetését, a diszkrimináció tilalmából levezethető jogosultságok terjedelmét, valamint ezekkel összefüggésben a tagállami költségvetés és a szociális ellátórendszer terhelhetőségének mértékét is megvizsgálja. Látni fogjuk, hogy a tagállami hovatartozás alapján történő megkülönböztetés tilalmát - az uniós polgár jogosultságainak részét képező szabad mozgáshoz való joggal együttesen - értelmező ítélkezési gyakorlat jelentős mértékben támogatja az Unió felsőoktatási célkitűzéseinek megvalósítását, és tényleges korlátját jelenti a tagállami cselekvésnek.

E folyamatok az egyértelműen megmutatkozó pozitív hatások mellett számos feszültségnek is forrásai. Ezek egyrészt a tagállami felsőoktatási rendszerek - még mindig jelentős - eltéréseiből adódnak, elsősorban a képzések minősége, létszámkorlát, tandíj vonatkozásában. Emellett további problémát jelentenek - az uniós jogalkotás eredményeinek ${ }^{26}$ ellenére is - a képesítések (diplomák) elismerésének akadályai, a nem megfelelő nyelvismeret, valamint a szükséges anyagi fedezet hiánya. Ez utóbbi ráadásul egyre problematikusabb, tekintettel a felsőoktatás terén Európaszerte megmutatkozó központi költségvetési megszorításokra.

1. táblázat. Hallgatói mobilitás az Európai Unió 27 tagállamában (2010)

\begin{tabular}{|l|c|c|c|c|}
\hline \multicolumn{1}{|c|}{ 27 EU } & $\begin{array}{c}\text { Bevándorló } \\
\text { hallgatók } \\
(\mathbf{1 0 0 0} \text { fö)* }\end{array}$ & $\begin{array}{c}\text { Kivándorló } \\
\text { hallgatók } \\
(\mathbf{1 0 0 0} \text { fö) }\end{array}$ & $\begin{array}{c}\text { A bev. és kiv. } \\
\text { hallgatók } \\
\text { számának } \\
\text { eltérése } \\
(\mathbf{1 0 0 0} \text { fö)** }\end{array}$ & $\begin{array}{c}\text { A bev. és kiv. } \\
\text { hallgatószám } \\
\text { eltérésének ará- } \\
\text { nya a fog. állam } \\
\text { összes hallgató- } \\
\text { jához képest }\end{array}$ \\
\hline Belgium & 35,1 & 10,6 & 24,5 & $5,5 \%$ \\
\hline Bulgária & 7,8 & 24,5 & $-16,7$ & $-5,8 \%$ \\
\hline Csehország & 25,9 & 12,2 & 13,7 & $3,1 \%$ \\
\hline Dánia & 17,6 & 5,5 & 12,1 & 5 \\
\hline
\end{tabular}

24 Jelenleg az EUMSZ 165. és 166. cikkei.

25 Bővebben az OMC müködéséröl, valamint ennek keretében elért eredmények és a bolognai folyamat öszszekapcsolódásáról lásd GoRnITZKA, Åse: The Open Method of Coordination as Practice - A Watershed in European Education Policy? Arena Working Paper, 2006, No. 16.

26 Lásd különösen az Európai Parlament és a Tanács 2005/36/EK irányelvét (2005. szeptember 7.) a szakmai képesítések elismeréséről, HL L 255, 2005. 09. 30., 22-142. 


\begin{tabular}{|c|c|c|c|c|}
\hline $\begin{array}{c}27 \text { EU } \\
\text { TAGÁLLAM }\end{array}$ & $\begin{array}{l}\text { Bevándorló } \\
\text { hallgatók } \\
\text { (1000 fö)* }\end{array}$ & $\begin{array}{l}\text { Kivándorló } \\
\text { hallgatók } \\
\text { (1000 fö) }\end{array}$ & $\begin{array}{l}\text { A bev. és kiv. } \\
\text { hallgatók } \\
\text { számának } \\
\text { eltérése } \\
(1000 \text { fó })^{* *}\end{array}$ & $\begin{array}{l}\text { A bev. és kiv. } \\
\text { hallgatószám } \\
\text { eltérésének ará- } \\
\text { nya a fog. állam } \\
\text { összes hallgató- } \\
\text { jához képest }\end{array}$ \\
\hline Németország & 129,7 & 92,2 & 37,5 & 1,5 \\
\hline Észtország & 2,1 & 3,9 & $-1,8$ & $-2,6$ \\
\hline Írország & 10,3 & 24,7 & $-14,4$ & $-7,4$ \\
\hline Görögország & 15,3 & 33,5 & $-18,2$ & $-2,8$ \\
\hline Spanyolország & 27,6 & 19,3 & 8,3 & 0,4 \\
\hline Franciaország & 46,3 & 51,8 & $-5,5$ & $-0,25$ \\
\hline Olaszország & 16,8 & 46,7 & $-29,9$ & $-1,5$ \\
\hline Ciprus & 1,9 & 25,7 & $-23,8$ & $-73,9$ \\
\hline Lettország & 0,7 & 5,3 & $-4,6$ & $-4,1 \%$ \\
\hline Litvánia & 0,3 & 10,5 & $-10,2$ & $-5,1 \%$ \\
\hline Luxemburg & 2,3 & 7,4 & $-5,1$ & $-94 \%$ \\
\hline Magyarország & 11,0 & 9,0 & 2 & $0,5 \%$ \\
\hline Málta & 0,0 & 2,2 & $-2,2$ & $-0,5 \%$ \\
\hline Hollandia & 36,0 & 14,9 & 21,1 & $3,2 \%$ \\
\hline Ausztria & 52,1 & 12,8 & 39,3 & 11,2 \\
\hline Lengyelország & 5,4 & 33,9 & $-28,5$ & $-1,3 \%$ \\
\hline Portugália & 3,8 & 19,8 & -16 & $-4,2 \%$ \\
\hline Románia & 3,9 & 40,0 & $-36,1$ & $-3,6 \%$ \\
\hline Szlovénia & 1,4 & 2,6 & $-1,2$ & $-1 \%$ \\
\hline Szlovákia & 7,1 & 31,5 & $-24,4$ & $-10,4 \%$ \\
\hline Finnország & 3,8 & 8,6 & $-4,8$ & $-1,6 \%$ \\
\hline Svédország & 12,8 & 15,4 & $-2,6$ & $-0,6 \%$ \\
\hline $\begin{array}{l}\text { Egyesült } \\
\text { Királyság }\end{array}$ & 186,4 & 14,5 & 171,9 & $6,9 \%$ \\
\hline
\end{tabular}

*Az EU-tagállamokból, EGT és tagjelölt országokból bevándorló, illetve ezen országokba kivándorló hallgatók száma.

Forrás: HoogenBoom: i. m., 49-50 és Eurostat ${ }^{27}$

** A pozitív számok a „nettó befogadó”, a negatív számok a „nettó küldő” államokat mutatják. 
Nem az Unión belüli hallgatói mobilitás mértéke jelent kihívást, hanem az egyensúly megbillenése. ${ }^{28}$ Néhány tagországban (amint azt az 1. táblázat is mutatja) a beutazó hallgatók száma jelentősen meghaladja a kiutazó hazai hallgatók arányát, és ez egyes esetekben kezelhetetlen oktatásszervezési problémákat, illetve pénzügyi terhet okoz az államnak. A tagállamonként eltérő képzési rendszerek említett eltéréseinek a következménye ugyanis, hogy egyes tagállamok a felsőoktatáshoz való hozzáférés szempontjából „vonzóbbak” lesznek. Leginkább azon országok viszonylatában láthatunk aránytalanságot, amelyeknél - a közös anyanyelvre, illetve a lakosság jelentős része által beszélt nyelvre tekintettel - a képzés nyelve azonos, ráadásul földrajzilag is egymás szomszédságában helyezkednek el. Ilyen sajátos kapcsolatról beszélhetünk Németország és Ausztria (Németország és Hollandia), illetve Franciaország és Belgium között. Mind Belgium, mind Ausztria felsőoktatási rendszere sokkal nyitottabb volt, mint a másik két országé, ennek következményeként pedig igen magas volt a belga felsőoktatásban a francia, az osztrák egyetemeken pedig a német hallgatók aránya, különösen az orvosi képzések voltak népszerüek. Végül mindkét (hallgatók „nettó importjával”29 érintett) tagállam a külföldi diákok bejutásának feltételeit szigorító intézkedéseket vezetett be. Ezen intézkedések kapcsán az Európai Unió Bíróságának is alkalma nyílt - immár az uniós polgár státusszal összefüggésben - a „határon átnyúló oktatáshoz való jog” terjedelmének, illetve korlátainak az értelmezésére.

A Bizottság kontra Belgium ügyben vitatott - a belgiumi Francia Közösség által bevezetett - szabály szerint a nem belgiumi érettségi bizonyítvánnyal rendelkező diákok nem férhetnek hozzá olyan tanulmányokhoz, amelyek „...nem lettek volna [a tanuló] számára hozzáférhetőek abban az országban, ahol a bizonyítványt kiállították". A Bíróság megállapította a Belga Királyság jogsértését, mivel az intézkedés eredményeképpen a más tagállamban szerzett középiskolai bizonyítvánnyal rendelkezők a Francia Közösség felsőoktatási intézményeiben szervezett képzésekhez belga érettségi bizonyítvánnyal rendelkezőkkel nem azonos feltételek mellett férhetnek hozzá. ${ }^{30} \mathrm{~A}$ Bizottság kontra Ausztria ügy tárgyát képező osztrák szabály értelmében pedig azoknak a végzősöknek, akik középiskolai bizonyítványukat nem Ausztriában, hanem egy másik tagállamban szerezték, és főiskolai vagy egyetemi tanulmányaikat az osztrák felsőoktatási rendszerben kívánják folytatni, a bizonyítvány bemutatásán túl bizonyítaniuk kell azt is, hogy abban az államban, ahol bizonyítványukat szerezték, megfelelnek a főiskolai és egyetemi oktatásba való bejutás feltételeinek (mint például sikeres felvételi vizsga letétele vagy a létszámkorlát által meghatározott legalacsonyabb tanulmányi szint elérése). A Bíróság szerint e szabály szintén alkalmas arra, hogy más tagállamok állampolgárait hátrányosan érintse, és ezáltal közvetett hátrányos megkülönböztetéshez vezet. ${ }^{31}$

28 VAN DER MeI, Anne Pieter: Free Movement of Students and the Protection of National Educational Interests: Reflections on Bressol and Chaverot. European Journal of Migration and Law, 2011, 125.

29 VAN DER Mel: i. m., 124.

30 C-65/03. számú, Bizottság kontra Belgium ügyben hozott ítélet (ECLI:EU:C:2004:402), 29. és 31. pontok.

31 C-147/03. számú, Bizottság kontra Ausztria ügyben hozott ítélet (ECLI:EU:C:2005:427), 47. és 75. pontok. 
Ausztria azzal védekezett az eljárás során, hogy a vitatott rendelkezés az osztrák oktatáspolitika központi célját szolgálja, azazhogy az állam a korlátlan bejutást valamennyi tanulmányi szintre lehetővé tegye - saját polgárainak. ${ }^{32} \mathrm{Az}$ intézkedés hiányában fennállna a veszélye annak, hogy a nyitottabb osztrák rendszert elárasztanák az olyan diákok jelentkezései, akiket a szigorúbb felvételi követelményeket támasztó tagállamokban nem vettek fel a felsőoktatási intézménybe. ${ }^{33} \mathrm{Az}$ osztrák kormány szerint ez komoly pénzügyi, szervezeti és személyzeti problémákat okozna, és veszélyeztetné az osztrák oktatási rendszer egységességét és pénzügyi egyensúlyát. A Bíróság azonban nem fogadta el ezt a hivatkozást. Nem adott helyt továbbá annak az érvnek sem, hogy a szabály az uniós joggal való visszaélés megelőzéséhez szükséges, mivel „...az Európai Unió egyik diákjának, aki középiskolai bizonyítványát nem Ausztriában, hanem egy másik tagállamban szerezte, az osztrák föiskolai és egyetemi oktatásba az osztrák középiskolai bizonyitvánnyal rendelkezőkkel azonos feltételekkel történő bejutása a diákok szabad mozgáshoz való jogának központi eleme". ${ }^{34}$

A Bíróság a tagállami hovatartozás alapján történő diszkriminációt tiltó EK 12. (jelenleg EUMSZ 18.) cikk mellett az EK 149., és az EK 150. cikkek (jelenleg EUMSZ 165. és 166., az oktatáspolitikáról szóló szerződéses rendelkezések) megsértését is megállapította mindkét ítéletében. ${ }^{35}$ Ezzel egyértelművé tette, hogy az Unió oktatáspolitikai hatáskörére vonatkozó szerződéses rendelkezések, habár a jogharmonizációt kifejezetten kizárják, annyiban mindenképpen gátját állják a tagállami szabadságnak - és ezzel lényegében egyfajta „soft” negatív jogharmonizációs hatást eredményeznek -, hogy a tagállamok e rendelkezésekben meghatározott elvekkel ${ }^{36}$ ellentétes intézkedést nem hozhatnak.

A két ítéletnek meglehetősen negatív visszhangja volt Ausztriában és Belgiumban. A tagállamok vezető politikusai - így Schüssel osztrák kancellár, ${ }^{37}$ illetve Rasmussen dán miniszterelnök ${ }^{38}$ - élesen bírálták a döntést, mondván, hogy az túlságosan kiterjesztően értelmezte a tagállamok által az Unióra ruházott oktatáspolitikai hatáskörök határait. A többségi jogirodalmi álláspont szintén bírálta a Bíróságot a két ország sajátos helyzete iránti „érzéketlensége” miatt. ${ }^{39}$

${ }^{32}$ E döntés célja Ausztria indoklása szerint az, hogy növelje a felsőfokú képesítéssel rendelkező osztrák állampolgárok arányát, amely az EU és az OECD tagállamai közül az ügy tárgyalása idején az egyik legalacsonyabb volt.

${ }^{33}$ Az osztrák kormány tárgyaláson ismertetett, orvosi tanulmányokra vonatkozó becslései szerint a középiskolai bizonyítvánnyal rendelkező külföldi - föleg német - jelentkezők száma ötszöröse a rendelkezésre álló helyeknek.

${ }^{34}$ C-147/03. számú, Bizottság kontra Ausztria ügyben hozott ítélet, 60-66. és 70. pontok.

35 C-147/03. számú, Bizottság kontra Ausztria ügyben hozott ítélet, 75. pont.

${ }^{36}$ Ezen elvek közül jelen ügyben kifejezetten a szakképzésbe történő bejutás megkönnyítésére, valamint az oktatók és a szakképzésben részt vevők mobilitásának ösztönzésére hivatkozott a Bíróság.

37 SZ-Interview mit dem künftigen Ratspräsidenten der EU: „Wolfgang Schüssel: 300 Sprachen und 500 Dialekte-das ist mein Europa." Süddeutsche Zeitung (31. Dezember 2005.).

38 Dänemark stellt Rolle des Europäischen Gerichtshofes in Frage. Der Standard (12. Jänner 2006.).

39 HILPOLD, Peter: Hochschulzugang und Unionsbürgerschaft - Das Urteil des EuGH vom 7. 7. 2005 in der Rs. C-147/03, Kommission gegen Österreich. Europäische Zeitschrift für Wirtschaftsrecht, 2005, 647; REICH, Norbert: Herkunftsprinzip oder Diskriminierung als Maßstab für Studentenfreizügigkeit? Europäische Zeit- 
2006-ban Ausztria és Belgium újabb - az alábbi, Bressol és Chaverot ügyben vitatott szabályozáshoz hasonló - kvótákat vezetett be, ${ }^{40}$ a Bizottság ezért ismét kötelezettségszegési eljárásokat indított velük szemben. ${ }^{41}$ Tíz hónappal később viszont felfüggesztette ezeket (ötéves időtartamra), ${ }^{42}$ mondván, hogy a tagállamok által előterjesztett adatok értelmében - legalábbis a hivatalos bizottsági álláspont szerint - a vitatott intézkedés hiányában veszélybe kerülne a közegészségügyi ellátás területi lefedettsége és minősége. ${ }^{43}$ Emellett Ausztria a Lisszaboni Szerződés mellékleteként olyan jegyzőkönyv elfogadását szerette volna elérni, amely biztosítja számára a korlátozó intézkedések lehetőségét a Németországból orvosi szakokra jelentkező diákok tekintetében. Még néhány nappal a 2007-es lisszaboni csúcs előtt ez volt az egyik legfontosabb, rendezésre váró kérdés. A Bizottság végül ígéretet tett a kötelezettségszegési eljárás öt évre történő felfüggesztésére, Ausztria pedig lemondott a jegyzőkönyv iránti igényéröl. ${ }^{44}$

A néhány évvel később a Bíróság elé került Bressol és Chaverot ügy előzményét szintén a belga Francia Közösség felsőoktatási intézményeibe iratkozó, nem belgiumi lakóhelyű diákok tömege jelentette, akik elsősorban az orvosi és a paramedicinális képzéseken kívántak részt venni. A növekedés elsősorban a francia diákok tömeges jelentkezésének volt köszönhetö. A Francia Közösség végül 2006-ban elfogadott egy rendeletet, amely szerint a Közösség egyetemei és főiskolái kötelesek korlátozni a beiratkozásuk időpontjában azon nem belgiumi illetőségủ diákok számát, akik első alkalommal iratkozhatnak be a rendeletben szereplő kilenc orvosi vagy paramedicinális képzés egyikére. ${ }^{45}$

A Bíróság e döntésében is megállapította, hogy a tagállami rendelet hátrányosabb helyzetbe hozza a nem belgiumi állampolgárokat. ${ }^{46}$ Ugyanakkor - szemben az elöbbi két ítélettel - elfogadta Belgium azon érvét, hogy a külföldi illetőségű diákok nagy száma miatt idővel egész Belgiumban hiány lehet a képzett egészségügyi dolgozókból, ami veszélyezteti a Francia Közösség közegészségügyi rendszerét. ${ }^{47}$ Következésképpen a vitatott szabályozás a közegészség védelmére hivatkozva iga-

schrift für Wirtschaftsrecht, 2009, 637; GARBEN, Sacha: Case C-73/08, Nicolas Bressol and Others, Céline Chaverot and Others v. Gouvernement de la Communauté française, Judgment of the Court of Justice (Grand Chamber) of 13 April 2010. Common Market Law Review, 2010/5, 1503-1504.

40 Az új osztrák szabályozás orvosi és fogorvosi szakokra határozott meg felvételi kvótákat: eszerint a helyek $75 \%$-át az Ausztriában, 20\%-át a más tagállamokban, 5\%-át pedig a harmadik államokban érettségi bizonyitványt szerzett hallgatók között kell elosztani; a belga reformintézkedés a helyek $70 \%$-át tartotta fent belga lakosoknak kilenc szakon (beleértve az orvosi és állatorvosi szakokat is).

41 Free movement of students: the Commission sends letters of formal notice to Austria and Belgium (Press Release, IP/07/76, Brussels, 24 January 2007).

${ }^{42}$ Az ötéves felfüggesztési időt a Bizottság azzal indokolta, hogy ezalatt az érintett államok részletesebb és pontosabb adatokat tudnak gyüjteni a korlátozó intézkedés igazolása érdekében.

43 Access to higher education: the Commission suspends its infringement cases against Austria and Belgium (Press Release, IP/07/1788, Brussels, 28 November 2007).

44 Garben: i. m., 1497-1498; GoldiRova, Renata: EU Seeks to Close its Institutional Wrangling (Lisbon, 18 October 2007), https://euobserver.com/institutional/24991 (2016. 04. 02.).

45 A Francia Közösség 2006. június 16-i rendelete a bizonyos, első ciklusú felsőoktatási képzéseken részt vevő diákok számának szabályozásáról (a Moniteur belge 2006. július 6-i száma, 34055.).

46 C-73/08. sz., Bressol és Chaverot ügyben hozott ítélet (ECLI:EU:C:2010:181), 46. pont.

47 C-73/08. sz., Bressol és Chaverot ügyben hozott ítélet, 46. és 68. pontok. 
zolható, ha a kérdést előterjesztő tagállami bíróság megállapítja, hogy annak elfogadása szükséges volt e cél érdekében, illetve nem léteznek más, kevésbé korlátozó intézkedések, amelyekkel e cél elérhető. ${ }^{48} \mathrm{~A}$ releváns adatok értékelését illetően ugyanakkor egy meglehetösen szigorú és részletes tesztet határozott meg az itélet, ${ }^{49}$ amelyen az elterjesztő belga alkotmánybíróság előtt végül csak három képzés ment át. ${ }^{50}$

\section{Megélhetési és képzési támogatások más tagállamok állampolgárainak a fogadó államban}

A tagállami rendszerek terhelhetőségének további próbáját jelenti a felsőoktatási intézmények hallgatóinak nyújtott szociális támogatások uniós jogi megítélése. A „fizikai jelenléthez" (például lakhatás, tömegközlekedés) szükséges források hiánya ugyanis éppúgy akadályát képezheti a felsőfokú tanulmányok folytatásának más tagállamokban, mint a hozzáférés létszámbeli korlátozása vagy a magas tandij. A szociális jellegü juttatásokhoz való jog tartalmát és feltételeit szintén a Bíróság döntései pontosították.

A Maastrichti Szerződés hatálybalépését követő ítéletek az uniós polgárokat megillető szabad mozgáshoz való jogból vezetik le a felsőoktatáshoz való egyenlő hozzáférést, ehhez kapcsolva a tagállamok „bizonyos mértékben” elvárt pénzügyi szolidaritási kötelezettségét is a megélhetési támogatások biztosítása terén. A tagállamok szolidaritási kötelezettségének ugyanakkor határt szab, hogy a gazdasági tevékenységet nem végző („inaktív”) uniós polgárok - ahová a diákok is tartoznak - nem jelenthetnek indokolatlan terhet a fogadó állam szociális ellátórendszerére. ${ }^{51}$ Éppen ezért külön igazolniuk kell, hogy a fogadó állam társadalmával valós kapcsolatot alakítottak ki, szemben a gazdaságilag aktív személyekkel (munkavállalók, önálló vállalkozók), akiknél az itt végzett gazdasági tevékenység önmagában elég ehhez. A korábbi ítélkezési gyakorlatot (nem csupán a hallgatók, hanem általában véve az uniós polgárok szociális juttatásaira vonatkozót) az inaktív polgárok jogainak meglehetősen kiterjesztő értelmezése jellemezte, ${ }^{52}$ de ma már nem ez a helyzet. A legújabb döntésekben a Bíróság megközelítése inkább abba az irányba fejlődik, hogy a gazdaságilag nem aktív személyek szabad mozgásának másodlagos jog által szabott korlátait „komolyan kell venni” . ${ }^{33}$ „Aki nem dolgozik, ne is egyék”

48 C-73/08. sz., Bressol és Chaverot ügyben hozott ítélet, 71., 75. és 76. pontok.

49 C-73/08. sz., Bressol és Chaverot ügyben hozott ítélet, 69-82. pontok.

50 VAN DER MeI: i. m., 24.

51 A Parlament és a Tanács 2004/38/EK irányelve (2004. április 29.) az Unió polgárainak és családtagjaiknak a tagállamok területén történő szabad mozgáshoz és tartózkodáshoz való jogáról, valamint az 1612/68/EGK rendelet módosításáról, továbbá a 64/221/EGK, a 68/360/EGK, a 72/194/EGK, a 73/148/EGK, a 75/34/ EGK, a 75/35/EGK, a 90/364/EGK, a 90/365/EGK és a 93/96/EGK irányelv hatályon kívül helyezéséröl, HL L 158., 2004. 04. 30., 77-123, 24. cikk, (1) bek. 7. pont.

52 Lásd többek között a C-456/02. sz., Trojani (ECLI:EU:C:2004:488), valamint a C-413/99. sz., Baumbast (ECLI:EU:C:2002:493) ügyekben hozott itéleteket.

53 Vö. NIC SHUIBHNE, Niamh: Limits Rising, Duties Ascending: The Changing Legal Shape of Union Citizenship. Common Market Law Review, 2015/4, 926-934. 
alapon a kivételek megszorító értelmezése helyett ${ }^{54}$ a Dano-itélet már sokkal inkább a keresőtevékenységet végzők és nem végzők közötti alapvető különbségre helyezi a hangsúlyt, illetve szigorúbban értékeli azt, hogy a szabad mozgás jogát gyakorló polgárok nem terhelhetik meg a fogadó tagállam szociális segítségnyújtási rendszerét. ${ }^{55}$

Mivel az ítélkezési gyakorlat e fordulata még csupán a legújabb, utóbbi néhány évben született döntésben mutatkozott meg, messzemenő következtetéseket nem fogalmazhatunk meg e tendencia jövőbeni alakulását illetően. Annyi mindenesetre igaz, hogy korábban láthattunk már példát évekig, akár évtizedekig töretlennek látszó ítélkezési gyakorlat egyértelmű irányváltására az integráció történetében. ${ }^{56}$

Egy lényeges különbséget viszont ki kell emelnünk a felsőfokú tanulmányokat nem folytató inaktív uniós polgárok és a hallgatók szociális juttatásait érintő újabb döntések között. Az elöbbiek egyértelmúvé tesznek egy olyan esetkört - a kizárólag a szociális segélyben részesülés szándékával érkezők körét -, amikor a 2004/38/ EK irányelv 24. cikkének (1) bekezdése ${ }^{57}$ alapján sem jár juttatás a más tagállambeli polgároknak, és a megkülönböztetés jogszerü. A tanulóknál viszont a Bíróság nem ment el odáig, hogy a hallgatói juttatások valamilyen csoportját kivegye az általános szabályok alkalmazási köréböl. Mindez összefüggésbe hozható azzal, hogy a diákok esetében a pusztán jogszerzésre irányuló motivációt eleve kizárja a tanulási cél. ${ }^{58}$ Ezenfelül egyre határozottabban előtérbe kerül az esetjogban a „diák mint sajátos státusz" értelmezése, tekintettel arra, hogy potenciálisan a jövőben hasznositható, gazdasági értékkel bíró munkaerőt jelentenek (szemben például a nyugdíjasokkal). Jacobs fötanácsnok kifejezetten ebből a szempontból értékeli és csoportosítja az

54 E megszorító értelmezés példájaként szolgál többek között: a C-22/08. és 23/08. sz., Vatsouras és Koupatantze ügyben hozott ítélet 44. pontja.

55 C-333/13. sz., Dano-ügyben hozott ítélet (ECLI:EU:C:2014:2358), 76-77. pontok. Hasonlóképpen döntött a Bíróság a C-67/14. sz., Alimanovic-ügyben (ECLI:EU:C:2015:597).

56 Lásd többek között az uniós hatáskör értelmezésére a kereskedelempolitika terén: 1/94. számú vélemény, A Közösség hatásköre a szolgáltatásokról és a szellemi tulajdon oltalmáról szóló nemzetközi szerződések megkötésére (ECLI:EU:C:1994:384).

57 „....a fogadó tagállam területén tartózkodó valamennyi uniós polgárt a Szerződés alkalmazási körébe tartozó területeken egyenlő bánásmód illet meg a fogadó tagállam állampolgáraival." [Kiemelés a szerzőtől.]

58 Bár meg kell jegyeznünk, hogy nem feltétlenül zárhatók ki olyan helyzetek, amikor az oktatás helyének megválasztását elsősorban az - átlagos megélhetési költségekhez, illetve tandíjhoz képest - kedvező szociális juttatások elérhetősége, és nem kifejezetten az oktatási intézmények által felkínált tanulmányok jellege, színvonala befolyásolja. 
európai diákmobilitás különböző változatait, ${ }^{59}$ a Giersch-ügyben ${ }^{60}$ pedig Luxemburg egyenesen a korlátozó intézkedését kimentő indokként hozta elő a külföldi tanulmányút során megszerzett tudás jövőbeni (hazai) hasznosításának célját.

2. táblázat. Érvek és ellenérvek a hallgatói mobilitás korlátozása mellett ${ }^{61}$

\begin{tabular}{|c|c|}
\hline $\begin{array}{c}\text { Tagállami érvek a tagállami autonómia és } \\
\text { a hallgatói mobilitás korlátozása mellett }\end{array}$ & $\begin{array}{c}\text { Érvek a hallgatói mobilitás } \\
\text { elősegítése mellett }\end{array}$ \\
\hline
\end{tabular}

Az Unió csak támogató, kiegészítő, összehangoló hatáskörrel rendelkezik a felsőoktatás szabályozása terén az EUMSZ 165. és 166. cikkei értelmében.

„Free rider” érvek:

- mivel a tagállami felsőoktatást a nemzeti költségvetésen keresztül az adófizetők finanszírozzák, valamilyen módon korlátozni kell a jelentkezők áradatát.

- a hallgatói migráció Európán belüli egyenetlen eloszlása miatt a „nettó küldő” államok „élősködnek” a „nettó fogadó” államok felsőoktatási infrastruktúráján (anélkül profitálnak a diák hazatérése után a képzett munkaerő teljesítményéböl, hogy a képzésbe invesztáltak volna).

A belső piac és az uniós jogrend megfelelő müködése kerül veszélybe, ha a tagállamok fennmaradó hatásköreiket nem az uniós jog elveinek tiszteletben tartásával gyakorolják.

„Free rider” ellenérvek:

- még ha a diákok közvetlenül nem is járulnak hozzá a fogadó állam adóbevételeihez, az egyetem környezetében müködő gazdasági létesítményeknek, illetve korlátozott mértékben a közvetett adókon keresztül a nemzeti költségvetésnek is bevételi forrást jelentenek; - a „nettó küldő” államoknak - legalábbis rövid távon - számolniuk kell azzal a kockázattal, hogy a külföldön diplomát szerző hallgatók nem (rögtön) térnek vissza hazájukba.

59 A fötanácsnok a szabad mozgás jogát gyakorló diákok két csoportját különíti el. Az elsőbe azokat sorolja, akik nyelvi akadályoktól függetlenül a más tagállamban kínált tanulmányokat azok kiváló színvonala miatt, illetve egyéni szakmai céljaikra vagy érdeklődési körükre tekintettel veszik igénybe. Tanulmányaik befejeztével esetükben sokkal valószínűbb, hogy származási országuktól eltérő országban fognak dolgozni, annak valamennyi gazdasági, társadalmi és kulturális következményével. Megszerzett tudásukkal ők igen fontos szereplőkké válnak - hozzájárulva az európai foglalkoztatási piac integrációjához is -, a tanulmányaiba való befektetésből a befogadó államnak tehát mindenképpen előnye származik. A másik csoportba pedig a „potyautas”-diákok tartoznak a főtanácsnok szerint, akik - az elöbbiekkel ellentétben - azért szeretnének bejutni a szomszédos nyitottabb oktatási rendszerbe, hogy származási országuk korlátozásait kikerüljék. A legtöbb ilyen esetben az oktatás a külföldi diákok által nagyon jól ismert vagy anyanyelvükkel megegyező nyelven folyik, illetve további vonzerőt jelent a földrajzi közelség. E diákok célja általában az, hogy a tanulmányok befejezésével származási országukban vállaljanak munkát (Jacobs főtanácsnok indítványa a C-147/03. sz., Bizottság kontra Ausztria ügyben, 41-42. pontok). A fötanácsnok e két kategória elkülönítéséből - a korábbi ítélkezési gyakorlat (C-212/97. sz., Centros-ügyben hozott ítélet [ECLI:EU:C:1999:126] 25. pont; C-436/00. sz., X és Y kontra Riksskatteverket ügyben hozott ítélet [ECLI:EU:C:2002:704], 42. pont) alapján - azt a következtetést vonta le, hogy az uniós joggal való visszaélés (vagyis a potyautasdiákok) kérdését minden esetben külön meg kell vizsgálni, mérlegelve az eset körülményeit és a bizonyítékokat. E követelményeknek viszont nem felel meg a fent vitatott osztrák szabályozással létrehozotthoz általános és nem konkretizált rendszer, amely automatikusan és különbségtétel nélkül valamennyi középiskolai bizonyítvánnyal rendelkező diákra kiterjed (az indítvány 56. pontja). Maga a Bíróság egyébként meglehetősen szűken értelmezi az alapszabadságokkal való visszaélés fogalmát (lásd például a letelepedés szabadságával összefüggésben a C-212/97. sz., Centros-ügyben hozott ítélet 27. pontját, bár hozzá kell tennünk, a letelepedés szabadságának jogát gyakorló vállalkozó esetében más a szerzett előny és annak fejében nyújtott gazdasági tevékenység viszonya, mint ugyanez a diákoknál).

60 C-20/12. sz., Giersch-ügyben hozott ítélet (ECLI:EU:C:2013:411).

61 A szerző összevetése a vonatkozó EUB-ítéletek és főtanácsnoki indítványok alapján. 
A külföldön tanuló diákok anélkül aratják le a más tagállam által nyújtott közoktatás elönyeit, hogy annak finanszírozásához (a szüleik által fizetett) nemzeti adójukon keresztül maguk is hozzájárulnának, és azt azzal sem „fizetik vissza”, hogy szakmai tevékenységüket később a fogadó tagállamban folytatnák.

Az állam pénzügyi egyensúlyának megőrzése érdekében szükséges a hallgatói mobilitás bizonyos mértékü korlátozása

- uniós harmonizáció hiányában a szabad mozgás jogával élő hallgató adott esetben kétszeresen is juttatásban részesülhet;

- az uniós jog alapszabadságaival való viszszaélés, ha azért megy el a hallgató más tagállamba tanulni, mert a saját tagállamában nem nyerne felvételt az adott szakon.

\section{Az ítélkezési gyakorlat Magyarország szemszögéből}

A fent bemutatott ítélkezési gyakorlat jelentősen hozzájárult a szabad mozgás jogával élni kívánó hallgatók arányának növekedéséhez az Unióban. ${ }^{62} \mathrm{Az}$ itt kimondott elvek és érvek tehát mindenképpen lényeges állomást jelentenek a bolognai célkitűzések elérésében, illetve az Európai Felsőoktatási Térség megvalósításában.

A hallgatói mobilitás intenzívebbé tételének azonban még mindig számos akadálya van, s ezt a szabad mozgáshoz való jog, illetve a diszkrimináció tilalmának kiterjesztő értelmezése sem tudja orvosolni. A mobilitási arány ugrásszerü emelkedése pedig nem is várható, amíg az uniós intézmények, illetve a bolognai folyamatban részt vevő tagállamok további lépéseket nem tesznek az akadályok csökkentése érdekében.

Kérdés marad viszont, hogy az esetjogban megszilárdult elvek és ezek alapján levezethető tagállami kötelezettségek, valamint az Unió egyéb „soft” eszközei - „valódi” jogharmonizációs hatáskör hiányában - ténylegesen milyen befolyással bírnak a tagállamok oktatáspolitikai döntéseire. Képesek-e ösztönözni a tagállamokat a további szükséges lépésekre, illetve meg tudják-e akadályozni a diszkrimináció elvével és a szabad mozgás jogát deklaráló rendelkezésekkel formálisan nem ütköző, de az uniós, illetve a bolognai felsőoktatási célkitüzésekkel alapvetően mégiscsak szembemenő tagállami intézkedéseket?

Magyarországon a felsőoktatás szervezését érintő problematikus intézkedések csekély százalékát lehetett eddig az uniós jog eszközeivel kezelni. A magyar felsőoktatási szabályozás ugyanis számos olyan kritikus elemtől szenved, amelyek csu-

62 Hoogenboom: i. m., 42. A más tagállam felsőoktatási intézményében való tanulás lehetőségét kihasználó hallgatók létszámának növekedését mutató pontos adatokat lásd OECD: Education at a Glance 2014: OECD Indicators. OECD Publishing, 2014, 372 és köv. 
pán közvetett módon érintik az alapszabadságok érvényesülését - nem sértik meg kifejezetten az EUMSZ vonatkozó rendelkezéseit, illetve megkülönböztető hatásuk csekély és indirekt módon ${ }^{63}$ érvényesül tagállamok közötti dimenzióban -, de ettől még a hatásuk jelentős.

Mint ahogyan fent már utaltunk rá, a szabad mozgás jogának tényleges müködését erőteljesen befolyásolják a tagállami felsőoktatási rendszerek eltérései - akár anélkül is, hogy bármiféle diszkriminatív intézkedés társulna hozzájuk - a képzési minőség és az oktatáshoz való hozzáférés (mind az anyagi, mind a létszámkorlátokból adódó) feltételei tekintetében. A határon átnyúló munkavállalás, letelepedés és szolgáltatásnyújtás lehetséges volumenét mindezek erőteljesen csökkenthetik. Nem véletlen, hogy a bolognai folyamatban részt vevő országok képviselői - a hallgatói mobilitás intenzitásának erősítése mellett - az Európai Felsőoktatási Térség megteremtésének központi tényezőjeként határozták meg a minőségbiztosítás továbbfejlesztését intézményi, nemzeti és európai szinten. ${ }^{64} A$ felsőoktatás minöségbiztosításának rendszere Magyarországon több szempontból sem tekinthető problémamentesnek (elég csak a 2011-es nemzeti felsőoktatási törvény [Nftv. ${ }^{65}$ módosításaira gondolnunk a Magyar Akkreditációs Bizottság testületi összetétel, illetve finanszírozási szabályai tekintetében ${ }^{66}$ vagy a testület ellenörzési hatásköre alól indokolatlanul mentesített képzésekre).

A minőségbiztosításnak emellett kulcseleme a felsőoktatási intézmények megfelelő szintű autonómiája, mert ahol nincs elegendő szabad mozgástér, ott eleve nem jöhetnek létre jól teljesítö, nemzetközi színvonalú alkotómühelyek ${ }^{67}$ Különösen fontossá válik ez akkor, amikor apadni látszanak az intézmények müködését mintegy „mesterségesen” is fenntartani képes állami támogatások, és az egyetemek egyre inkább alternatív forrásszerzési lehetőségekre kényszerülnek. Magyarországon a felsőoktatás állami támogatásának összege - az Európa-szerte megmutatkozó központi költségvetési megszorításhoz képest is - jelentősen csökkent az utóbbi években, ${ }^{68}$ ugyanakkor ezt nem ellensúlyozta a kormányzat a gazdálkodási auto-

63 Nyilvánvalóan ellentétes az egyenlő elbánás elvével többek között a keretszámok meghatározásának - központilag történő és kifejezetten a népszerű szakokat (köztük a jogász és közgazdászképzést) hátrányosan érintő rendszere Magyarországon, amely egyenlőtlen versenyfeltételeket teremt az egyes képzések és képzőintézmények között. Az intézkedés (mind tényleges, mind potenciális) érintettjei - azaz a hallgatók és a felsőoktatási intézmények - ugyanakkor lényegében egy tagállam területén belül maradnak.

64 „Az Európai Felsőoktatási Térség megvalósítása.” Kommüniké a felsőoktatásért felelős miniszterek konferenciájáról, Berlin, 2003. szeptember 19.

65 2011. évi CCIV. törvény a nemzeti felsőoktatásról.

66 A kormányzati függőség növekedése és a finanszírozási szabályok változása miatt 2013-ban a testület európai felsőoktatási akkreditációs szervezetben (ENQA, European Associaton for Quality Assurance in Higher Education) betöltött „teljes tag” státuszát is felfüggesztették. Az ENQA végül 2015-ben visszaállította a MAB teljes tagságát, de a függetlenség tekintetében csupán „lényegi” (azaz nem teljes) megfelelést állapított meg.

67 DEÁk Dániel: Autonómia és egyetem. In: Hrubos lldikó (szerk.): Autonómiák a felsőoktatásban. Budapesti Corvinus Egyetem Nemzetközi Felsőoktatási Kutatások Központja, Budapest, 2013, 12.

68 Reálértéken számítva 2005 és 2013 között ez majdnem 50\%-os csökkenést jelent (Felsőoktatási ténytár, 2013). 
nómia kiterjesztésével (sőt éppen ellenkezőleg). ${ }^{69} \mathrm{Az}$ Nftv. meglehetősen radikális változtatásokat hozott a szervezeti autonómia terén is a rektor mozgásterének egyre nyilvánvalóbb szükítésével, 2014-től az egyetemek gazdálkodását felügyelő kancellárok - kormány általi - kinevezésével, valamint a 2016-tól működő konzisztóriumokkal (amelyek részben átveszik a rektorok feladatait stratégiai kérdésekben).

A fentiek mind igen súlyos problémái a magyar felsőoktatási rendszernek, a ténylegesen kikényszeríthető alapszabadságokhoz való közvetett viszonyukra tekintettel viszont nehezen ragadhatók meg az uniós jog mércéi alapján. A személyek szabad mozgásán kívüli alapszabadságok érvényesülését ráadásul az is kizárja - fő szabály szerint -, hogy az állami közfeladatok körébe tartozó felsőoktatás alapvetően nem tekinthető gazdasági tevékenységnek (olyan értelemben, hogy a belső piaci szabályok alkalmazása szempontjából visszterhes szolgáltatásnak minősülne). ${ }^{70}$ Ugyanígy problematikus az EU Alapjogi Chartája által védett oktatáshoz való jogra való hivatkozás, tekintve, hogy ez csak „az uniós jog alkalmazása során” "71 hívható fel az uniós bírósági fórumok előtt. ${ }^{72}$

A fenti kérdéseket érintő uniós elvárások inkább a már említett „soft law” dokumentumokban (tanácsi ajánlások, bizottsági közlemények, szakmai jelentések: lényegében a nyitott koordinációs módszer eszközei) vannak megfogalmazva, amelyeknek a Bíróság előtt legfeljebb az érvelést támogató szerepe lehet ${ }^{73}$ a kötelező jogi erejü szabályok mellett.

Soft law formában ${ }^{74}$ került sor a felsőoktatás finanszírozásának kérdésével öszszefüggő uniós álláspont megfogalmazására is. A Bizottság alapvetően fontosnak tartja a magánforrások arányának növelését a felsőoktatásban, de ez nem jelenti azt, hogy államitámogatás-kivonásra biztatná a tagállamokat. Az uniós célkitüzés csak az arányok megváltoztatása, a Bizottság ugyanakkor mind a köz-, mind a magánfinanszírozások esetében lényegesnek tartja a forrásösszegek növelését, hangsúlyozva, hogy a „...fenntartható felsőoktatás alapja továbbra is az állami beruházás kell hogy maradjon". ${ }^{75}$ Magyarországon a költségvetési források radikális csökken-

69 KovÁTs Gergely: Recent Developments in the Autonomy and Governance of Higher Education Institutions in Hungary: the Introduction of the „Chancellor System”. In: Berács József-Iwinska, Julia-Kováts GergelyMatei, Liviu (szerk.): Central European Higher Education Cooperation Conference Proceedings. Corvinus University of Budapest Digital Press, Budapest, 2015, 31.

70 Lásd ezzel összefüggésben a fent idézett, 263/86.sz., Humbel-ügyben hozott ítéletet.

71 Charta 51. cikk (1) bekezdés.

72 Lásd ezzel összefüggésben a C-614/12. és C-10/13. sz., Dutka és Sajtos egyesitett ügyekben hozott végzést (ECLI:EU:C:2014:30), amelyben a Bíróság a köztisztviselők jogállásáról szóló 1992. évi XXIII. törvény 17. §-át (a közszolgálati jogviszony indokolás nélküli megszüntetése) vizsgálta a Bíróság a Charta 30. cikke alapján, amely szerint minden munkavállalónak joga van az indokolatlan elbocsátással szembeni védelemhez. A Bíróság saját hatáskörének hiányát állapította meg az ügyben, hivatkozva arra, hogy a Ktv. alapján hozott határozatok nem „az uniós jogot végrehajtó nemzeti szabályozással kapcsolatosak”.

73 De még ez a fajta utalás is ritka volt eddig az ítélkezési gyakorlatban. „Üdítő kivételként” lásd a fenti C-20/12. sz., Giersch-ügyben hozott ítéletet.

74 A Bizottság közleménye: Az egyetemek szerepe a tudás Európájában. COM(2003) 58 végleges. COM(2005) 152 végleges. A Bizottság közleménye: Európa szellemi tőkéjének mozgósítása: tegyük lehetővé az egyetemek teljes körü hozzájárulását a lisszaboni stratégiához!

75 A Bizottság közleménye: Az európai felsőoktatási rendszerek által az intelligens, fenntartható és inkluzív növekedés terén tett hozzájárulás növelése. COM(2011) 567 végleges. 
tése és a forráselosztás kiszámíthatatlansága nyilvánvalóan ellentétes ezzel az elvvel, de ez ellen uniós bírósági fórumok előtt fellépni aligha lehet. Az alapszabadságok, illetve az oktatáshoz való jog megsértése itt (a fent kifejtett akadályok miatt) szintén nem hivatkozható.

Felmerül ugyanakkor a kérdés, hogy a forráselosztás kiszámíthatatlan és szelektív rendszerére tekintettel szóba jöhet-e a versenyszabályokkal, nevezetesen az állami támogatások tilalmával (EUMSZ 107. cikk 1. bekezdés) való ütközés. A Bíróság megállapítása az állami felsőoktatás nem gazdasági természetére vonatkozóan itt is érvényes, viszont az újabb ítélkezési és bizottsági gyakorlat tendenciáit figyelembe véve ez akár változhat is. Egyre többször találkozunk ",határesetekkel”, ${ }^{76}$ amikor meglehetősen nehéz meghúzni a gazdasági tevékenység ${ }^{77}$ és a nem gazdasági érdekböl végzett szolgáltatás közötti határvonalat. E bizonytalan kategóriák leginkább a humán szolgáltatásoknál (különösen az egészségügyi szektorban) jelennek meg, mivel a piaci mechanizmusok ezeken a területeken is egyre meghatározóbban érvényesülnek.$^{78}$ llyenfajta elhatárolási kérdésekkel a felsőoktatási szektorban is találkozhatunk,$^{79}$ mivel az állami szerepvállalás csökkenésének általános tendenciája az egyetemek vállalkozói funkcióinak, és ily módon azon tevékenységi körének kiterjedésével jár együtt, amelyek az uniós versenyszabályok hatálya alá tartoz(hat)nak. ${ }^{80}$ Innen nézve pedig már az sem kizárt, hogy az EUMSZ 107. cikke alapján vizsgálhatók azok az állami forrásból, eseti alapon nyújtott hazai támogatások, amelyek egyes képzéseket, ${ }^{81}$ illetve intézményeket indokolatlanul kedvezőbb helyzetbe hoznak a „versenytársakhoz" képest. ${ }^{82}$ llyen irányú változás viszont egyelőre kevéssé látszik valószínünek, figyelembe véve az általános érdekű szolgáltatásokat érintő uniós szabályozás és esetjog (nagyjából a 2000-es évek közepétöl érzékelhető) fordulatát, ${ }^{83}$ amelynek eredménye, hogy az uniós jog immár nagyobb mozgásteret hagy a tagállamok számára, hogy a piaci körülmények között végzendö tevékenységeket meghatározzák. ${ }^{84}$

76 Lásd többek között a C-475/99. sz., Ambulanz Glockner-ügyben (ECLI:EU:C:2001:577) és a C-203/99. sz., Henning Veedfald-ügyben (ECLI:EU:C:2001:258) hozott ítéletekben vizsgált egészségügyi szolgáltatásokat, valamint a szakképzés tekintetében: 2006/225/EK: A Bizottság határozata (2005. március 2.) a szakképzési intézmények átszervezésére vonatkozóan Olaszországban létrehozott támogatási rendszerröl, HL L 81, 2006. 03. 18., 25-35.

77 A gazdasági tevékenység meghatározását lásd A Bizottság közleménye (2004. május 12.). Fehér Könyv az általános érdekű szolgáltatásokról, $\operatorname{COM(2004)~} 374$ végleges. 44. pont.

78 GIDEON, Andrea: Higher Education Institutions and EU Competition Law. European Competition Law Review, 2012/5, 172.

79 Lásd különösen C-109/92. sz., Wirth-ügyben hozott itéletet (ECLI:EU:C:1993:916) és a C-281/06. sz., Jundt-ügyben hozott ítéletet (ECLI:EU:C:2007:816).

80 GIDEON: i. m., 169-170.

81 Nyilvánvalóan itt olyan képzésekre kell gondolnunk, amelyek nem csupán a tagállami piacon versenyeznek.

82 Vö. GIDEON: i. m., 181-183; HuBER, Stefan-PRIKOszovits, Julia: Universitäre Drittmittelforschung, oder: Was das EG-Beihilfenrecht mit der Vollkostenrechnung zu tun hat, 2008 (kézirat).

http://www.wissenschaftsmanagement-online.de/sites/www.wissenschaftsmanagement-online.de/files/ migrated_wimoarticle/Huber-Prikoszovits-Text.pdf (2016. 04. 02.).

${ }^{83}$ Erröl bővebben lásd: HoRVÁTH M. Tamás: Fordulat a közszolgáltatásokkal kapcsolatos uniós politikában. In: Horváth M. Tamás (szerk.): Külön utak. Közfeladatok megoldásai. Dialóg Campus, Budapest, 2013, 193-200.

84 VARJu Márton: A közszolgáltatások szabályozása az Európai Unióban. In: Horváth M. Tamás (szerk.): Kilengések. Közszolgáltatási változások. Dialóg Campus, Budapest, 2013, 109-115 és 109. Lásd még T-289/03. 
A felsőoktatás magyarországi helyzetének kritikus pontjai közül tulajdonképpen egy olyan elemet tudunk kiemelni, ahol az uniós jogi kötelezettségekre hivatkozva valamilyen szinten orvosolni lehetett a problémát: ezek a „röghöz kötésként” elhíresült hallgatói szerződések. Hozzá kell tennünk, a megoldás itt sem tökéletes, távolról sem. Az Nftv., illetve annak felhatalmazása alapján kibocsátott, 2012 augusztusában hatályba lépett kormányrendelet szerint az állami ösztöndíjas hallgatók olyan szerződést kötelesek kötni a magyar állammal, amelynek értelmében az oklevél megszerzését követően húsz éven belül a tanulmányi idő kétszeresének megfelelő időtartamban hazai munkaviszonyt létesítenek és tartanak fent.

Az alapvető jogok biztosának indítványára 2012. július 3-án hozott határozatában a magyar Alkotmánybíróság megállapította a fenti szabályok formai alkotmányellenességét. $A z A B$ szerint a kormányrendelet - mivel az érintett hallgatók mủvelődéshez és a foglalkozás szabad megválasztásához füződő jogát is közvetlenül érinti - az Alaptörvény I. cikk (3) bekezdésébe ${ }^{85}$ ütközik, így mind a felhatalmazást adó Nftv. rendelkezést, ${ }^{86}$ mind a kormányrendeletet ${ }^{87}$ megsemmisítette. ${ }^{88}$ Tartalmi alkotmányossági kérdések vizsgálatába tehát az $A B$ nem ment bele - az uniós szabályokkal való összhang kérdésére is a formai kritériumokkal összefüggésben tért ki (azaz valóban alapjogot érint-e a hallgatói szerződés, amire tekintettel törvényi szabályozás szükséges). Az AB úgy véli, hogy „[a]z az egyetemi hallgató, aki felsőfokú tanulmányai befejezését követően nem Magyarországon, hanem [...] egy másik uniós tagállamban vállal munkát, a foglalkozás szabad megválasztásához való jogát gyakorolja. Ezt a szabadságot az Európai Unió alapszerződése [EUMSZ 45. cikk], illetőleg a másodlagos uniós jog a szabad mozgáshoz való jog részeként részesíti védelemben. Ezért a munka és a foglalkozás szabad megválasztásához füződő jog értelmezése során az Alkotmánybíróság nem hagyhatja figyelmen kívül a vonatkozó uniós szabályokat és az Európai Bíróság releváns joggyakorlatát." A Morgan és Bucher ügyben hozott ítéletet ${ }^{89}$ külön is idézte, hangsúlyozva, hogy az

sz., BUPA és társai ügyben hozott ítélet (ECLI:EU:T:2008:29); A Bizottság közleménye az európai uniós állami támogatási szabályoknak az általános gazdasági érdekű szolgáltatások nyújtásának ellentételezésére való alkalmazásáról. HL C 8, 2012. 01. 11., 4-14.

85 „Az alapvető jogokra és kötelezettségekre vonatkozó szabályokat törvény állapítja meg.”

86 Nftv. 110. $§(1)$ bekezdés 23. pont.

87 2/2012. (I. 20.) Korm. rendelet a magyar állami ösztöndíjas és magyar állami részösztöndíjas hallgatókkal kötendő hallgatói szerződésekről.

88 32/2012. (VII. 4.) AB határozat, 61. pont.

$89 \mathrm{Az}$ érintett jog, azaz munkavállalók vagy uniós polgárok szabad mozgása meghatározása terén a fenti ügyekben látszó bizonytalanság az AB-eljárás során is megmutatkozott. Az indítványt előterjesztő alapjogi biztos a munkavállalás szabadságát deklaráló uniós jogi rendelkezésekre (EUMSZ 45. és az Alapjogi Charta 15. cikkei) hivatkozott, de ezen érve alátámasztásaként már az uniós polgárok szabad mozgását értelmező ítéleteket hozta elő. Sőt - mint ahogyan erre Vincze Attila is felhívja a figyelmet - az Alkotmánybíróság tulajdonképpen „eltévesztette” az alkalmazandó esetjogot, és a munkavállalók szabad mozgásához való jog értelmezési példájaként hozta fel, holott a Morgan and Bucher ügyben hozott ítélet az uniós polgárok jogairól szól. (VINCZE Attila: Az Alkotmánybíróság határozata a hallgatói szerződések alkotmányosságáról A foglalkozás megválasztása és a rendeleti jogalkotás. Jogesetek Magyarázata, 2012/3, 25-26.) 
ott vitatott szabály ${ }^{90}$ a szabad mozgáshoz és tartózkodáshoz való uniós jog korlátozását valósította meg. Az AB azt is elismerte, hogy „...az Alkotmánybíróság által nyújtott alapjogvédelem szintje semmiképpen sem lehet alacsonyabb, mint a nemzetközi [...] jogvédelem szintje. [...] Még inkább igaz ez az Európai Unió jogát érintően."

Az alkotmánybírósági gyakorlat „EU-konform” fejlődése szempontjából természetesen e kitételnek jelentősége van. ${ }^{92}$ Vitatható ugyanakkor (különösen a fent vizsgált ítéletekkel összenézve), hogy mennyiben éri el a szabad mozgáshoz való jog Bíróság által garantált védelmének szintjét a formai szempontok vizsgálatára kor-

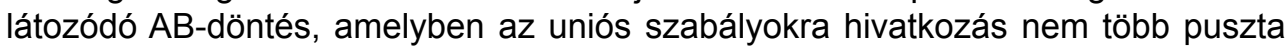
díszítőelemnél. ${ }^{93}$ Főként megkérdőjelezhető ez a későbbi fejlemények tükrében; az Alaptörvény 2013. április 1-jén hatályba lépett negyedik módosítása ugyanis kiegészítette annak XI. cikkét egy új, a röghöz kötést szentesítő rendelkezéssel, ${ }^{94}$ „orvosolva" ezzel az AB által kifogásolt formai hibát.

A hallgatói szerződés hazai szabályozásának vizsgálatára később (2013-ban) ún. „EU-pilot” eljárás keretében is sor került. A Bizottság és a magyar kormány álláspontja több ponton is eltért a hallgatói szerződés jogszerüségét illetően. A kormány érvei szerint az állami ösztöndijszerződés csupán egy opció, amely mellett a hallgatónak számos lehetősége („Diákhitel 2”, önerőből finanszírozás és munkáltatói szerződés) van a képzésének finanszírozására; a konstrukció az Európa 2020 stratégiával összhangban a "közjót” - vagyis hogy a diplomás értelmiségiek a hazai munkaerőpiacon megjelenjenek - szolgálja, és az arányosság elvének is megfelel. ${ }^{95}$ A Bizottság viszont - hasonlóképpen, mint az alapjogi biztos az $A B$ elé terjesztett indítványában - úgy vélte, hogy itt nem önként vállalt szerződéses kötelezettségről van szó, mivel a hallgató valójában nem rendelkezik választási lehetőséggel. ${ }^{96} \mathrm{Nem}$ győzték meg továbbá a közjóra, illetve az intézkedés arányosságára alapozott érvek sem. Összességében nézve az AB elötti eljárásnál az „EU-pilot” eljárás végül eredményesebbnek bizonyult annyiban, hogy a Bizottság és a magyar kormány egyeztetése a szerződéskötést egyoldalú hallgatói nyilatkozattá, a magyarországi munka-

90 A Morgan and Bucher ügyben hozott ítéletben vitatott Bundesausbildungsförderungsgesetz értelmében a támogatást kérelmező hallgatónak legalább egy évet Németország területén található oktatási intézményben kell töltenie ahhoz, hogy egy másik tagállamban folytatott tanulmányához képzési támogatást kapjon.

91 32/2012. (VII. 4.) AB határozat, 41. pont.

92 Erröl bővebben lásd VINCZE: i. m., 25.

93 A "díszítőelem" terminus elméleti hátteréröl bővebben lásd BeNCze Mátyás: Díszítőelem, álcázóháló vagy tartóoszlop? A magyar büntetőbírói gyakorlat viszonya az alkotmányhoz. Fundamentum, 2007/3, 5-21.

94 Magyarország Alaptörvénye (2011. április 25.) XI. cikk (3) bekezdés.

95 A kormány szerint az arányosság elvének betartását szolgálja, hogy a 20 éven belül szabadon ütemezhető a hazai munkavégzés, továbbá, hogy a ledolgozandó időszak számításának alapja csak a támogatott formában igénybe vett aktív félév, azaz öt hónap.

96 Ez az érv Magyarországra nézve különösen igaznak tünik a World Economic Forum egy friss elemzése értelmében (https://agenda.weforum.org/2015/10/the-11-most-expensive-countries-for-a-university-degree/), amely azt vizsgálta, hogy a 2014/15 akadémiai évben a szülők a fizetésük (az adott országban átlagosnak tekinthető fizetéssel számolva) hány százalékát költik felsőoktatási intézmény (alapszakos) képzésének tandíjára. Az elemzés $92 \%$-os aránnyal Magyarországot hozta ki elsőnek a vizsgált negyven állam közül. Hazánk után a legköltségesebb kilenc ország ugyanezen számítási módszer alapján (sorrendben) a következő: 2. Románia, 3. Észtország, 4. Chile, 5. Malajzia, 6. USA, 7. Ukrajna, 8. Litvánia, 9. Egyesült Királyság, 10. Szingapúr. 
vállalási időt pedig a képzési idő tartamává „szelídítette” - ez kellett ugyanis ahhoz, hogy a Bizottság végül ne indítson Magyarországgal szemben kötelezettségszegési eljárást az Unión belüli munkavállalás szabadságának megsértése miatt.

\section{5. Összegzés}

Az Unió oktatáspolitikai célkitüzéseinek megvalósítása szempontjából meghatározó szerepe van az ítélkezési gyakorlatban kidolgozott jogelveknek. A Bíróság döntései egyértelmüen hozzájárultak a tanulmányi célú szabad mozgás akadályainak lebontásához, jóval intenzívebben ráadásul, mint az Unió tényleges oktatási hatáskörén (EUMSZ 165. és 166. cikkei) alapuló stratégiai dokumentumok és cselekvési tervek, illetve a bolognai folyamat eszköztára.

Mindez annak ellenére van így, hogy a Bíróság igen kivételesen, és csupán támogató, kiegészítö érvként hivatkozik a bolognai célokra, ${ }^{97}$ ugyancsak ritkán a felsőoktatással kapcsolatos uniós stratégiai dokumentumokra. A fent bemutatott ítéletek érvelése jellemzően a személyek szabad mozgását szabályozó jogi rendelkezéseken, valamint a kapcsolódó gazdasági, szociális és politikai megfontolásokon alapul. ${ }^{98} \mathrm{Az}$ uniós jog e két, alapvetően elkülönülő területének céljai viszont részben - a határon átnyúló mobilitás elősegítése tekintetében - megegyeznek, ${ }^{99}$ így az eredmény mégiscsak az, hogy a szabad mozgáshoz való jogot értelmező ítélkezési gyakorlat a „soft law” szintjén létező felsőoktatási célkitüzések valódi, jogi kikényszerítéséhez járul hozzá. ${ }^{100}$

97 Inkább a főtanácsnoki indítványokban láthatunk a bolognai célokra alapozott érveket, de itt is csak elvétve. Lásd Colomer fötanácsnok C-11/06. és C-12/06. sz., Morgan és Bucher egyesített ügyekben ismertetett indítványának (ECLI:EU:C:2007:174) 44-47. pontjait, valamint Sharpston főtanácsnok C-73/08. sz., Bressol és Chaverot ügyben ismertetett indítványának (ECLI:EU:C:2007:174) 2. lábjegyzetét.

98 Láthatóan akkor is ezek az érvek hangsúlyosak az ítéletekben, amikor a Bizottság kötelezettségszegési keresetében mind az uniós polgárok szabad mozgáshoz való jogát deklaráló EUMSZ 21. cikket, mind pedig az Unió oktatáspolitikájának alapjait rögzítő EUMSZ 165. és 166. cikkeket megjelöli (lásd a fenti Bizottság kontra Ausztria és Bizottság kontra Belgium ügyeket), illetve a tagállami bíróság ezek mindegyikének értelmezését kéri az előzetes döntés iránti kérelmében (lásd a Bressol és Chaverot ügyet).

99 Így a bolognai folyamat egyik alappillérét képezi a hallgatói mobilitás előmozdítása, és szintén a célok között szerepel a megélhetési támogatások hordozhatóságának lehetővé tétele is.

100 Ez a folyamat tulajdonképpen sajátos változata a „soft law keményedésének”, hiszen nem maga a Bolognai Nyilatkozat, illetve az ezt követő miniszteri találkozók dokumentumai vagy az uniós vívmányok válnak kötelező erővel bíró jogi aktussá, hanem a „soft law” és a „hard law” (ez utóbbi alatt a személyek szabad mozgására vonatkozó rendelkezéseket értjük) célkitüzéseinek egybeesése teszi lehetővé az Unió Bírósága előtti kikényszerítést. A soft law keményedésének klasszikus (már ha nevezhetjük egyáltalán így) példáit - többek között az Alapjogi Charta, illetve a belügyi és igazságügyi együttmüködés terén meghozott intézkedések „kemény joggá” fejlődésének eseteit - mutatja be: TERPAN, Fabien: Soft Law in the European Union-The Changing Nature of EU Law. European Law Journal, 2015/1, 91-94. 


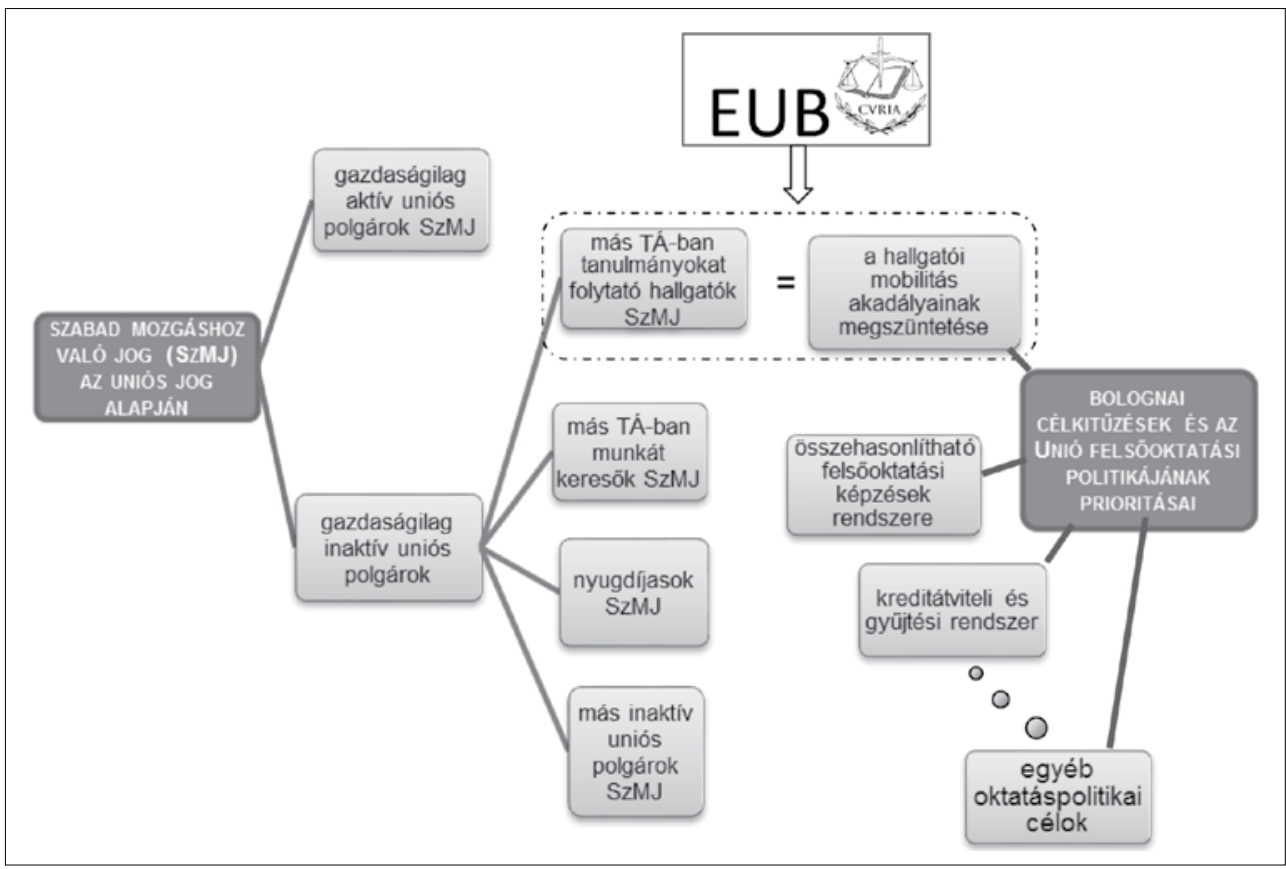

1. sz. ábra. A Bíróság ítélkezési gyakorlata és a hallgatók szabad mozgása Európában

A fent vizsgált ítéletekben kimondott elvek nem meglepő módon igen erős feszültséghez vezetnek az Unió és a tagállamok között, mivel ez utóbbiak - a ráruházott hatáskörök elvére hivatkozva - nehezen fogadják el, hogy az Unió számára juttatott, limitált kompetenciák és eszközrendszer ellenére az esetjog meglehetösen szük határokat szab szakpolitikai cselekvéseiknek. A tagállamok szerint az ítélkezési gyakorlat nem veszi kellőképpen figyelembe a nemzeti oktatási és pénzügyi érdekeket, ${ }^{101}$ a tagállami autonómia iránti igényt az oktatási politika meghatározása terén, illetve - az orvosi és paramediciális kurzusok esetében - a közegészségügyi rendszer minőségét érintő potenciális veszélyeket. ${ }^{102} \mathrm{~A}$ konfliktus kiéleződése különösen jól érzékelhető volt a fenti Bizottság kontra Ausztria és Bizottság kontra Belgium ítéleteket követő eseményeket nézve.

A felsőoktatás Európában látható átalakulásának különböző állomásai, az elmúlt néhány évtizedben jellemzően minden országot érintő kihívások szintén nyomon követhetőek az ítélkezési gyakorlat fejlődéstörténetében. A korai - a Maastrichti Szerződést megelőző - esetjog a felsőoktatást elsősorban „szakképzésként”, az emberi erőforrás termelésének eszközeként értelmezte, összhangban azzal az egész Európában jellemző folyamattal, hogy az egyetemi képzési profil az akadémiai orientációtól távolodik és egyre erőteljesebben a munkáltatói szektor igényeinek megfelelően

\footnotetext{
101 VAN DER Mel: i. m., 124.

102 VAN deR Mel: i. m., 125.
} 
alakul. Később a Bíróság már egyértelmüen az „európai polgári jogok” részének tekinti a felsőoktatáshoz való hozzáférés jogát más tagállamban, ami nem csupán az uniós polgár státuszának Maastrichti Szerződéssel való bevezetésével függ össze, hanem a felsőfokú képzés iránti kereslet általánossá válásával (a „tömegesedés” jelenségével) Európában és a felsőoktatáshoz való hozzáférés jogának jellemzően kiterjesztő értelmezésével. Mindennek egyenes következménye a „határon átnyúló igények" (illetve az ezzel összefüggő jogviták) számának növekedése is. A felsőoktatás gazdasági haszna pedig megint előtérbe kerül a gazdasági és pénzügyi válság kezdetét követő években - ezt mutatják a tagállami érvek, a fötanácsnoki indítványok, de maguk a bírósági ítéletek is.

A hallgatói migráció intenzitásának erösödésével a migráció egyenetlensége által generált problémákat a Bíróság elé kerülő esetek is tükrözik - nem véletlen, hogy a felsőoktatáshoz való hozzáféréssel, illetve hallgatói támogatással kapcsolatos esetek jelentős része pont Ausztria és Belgium intézkedéseit érintette. ${ }^{103} \mathrm{~A}$ válság hatásaival és az európai államokban általánosan jellemző költségvetési megszorításokkal párhuzamosan megnövekedett a felsőoktatást érintő szociális támogatási intézkedésekkel összefüggő ügyek száma is a Bíróság elött.

Az ítélkezési gyakorlat alapján úgy tünik, mintha a Bíróság „megértőbb” lenne a 2008-as gazdasági és pénzügyi válság időszakában, illetve az azt követő egy-két évben hozott döntéseiben a tagállami költségvetési megfontolások irányába, illetve fokozottabban figyelembe venné az Unión belüli hallgatói migráció által generált problémákat, és érzékenyebb lenne a tagállamok költségvetési terheire vonatkozó érvekre. E megközelítés viszont - mivel az ítélkezési gyakorlatban egyértelmüen kialakított elv az, hogy a tagállami költségvetési megfontolások nem szolgálhatnak kimentési alapként ${ }^{104}$ - inkább burkoltan jelenik meg, és az ügy hátterét, elö- és utóéletét is figyelembe véve következtethetünk erre. Ezt a következtetést támasztja alá különösen, ha a fenti Bressol és Chaverot itélet végső konklúzióját összevetjük a többi elemzett döntéssel. Szintén hasonló tendenciát láthatunk a felsőoktatás támogatásával összefüggő ítélkezési gyakorlat alapján, ${ }^{105}$ valamint, ha az oktatás mellett megvizsgáljuk az általános gazdasági érdekü szolgáltatások más formáival (így különösen az egészségügyi és szociális szolgáltatásokkal) összefüggő ítélkezési gyakorlatot. ${ }^{106}$

A Bíróság vizsgált ítélkezési gyakorlata csak egyik mutatója azoknak a komplex folyamatoknak, amelyek folyamatosan alakítják a felsőoktatás funkcióját, rendeltetését, a felsőoktatáshoz való hozzáférés jogának értelmezését. A kihívások több más

103 A fent vizsgált ügyeken kívül lásd még többek között: C-75/11. sz., Bizottság kontra Ausztria ügyben hozott itélet (ECLI:EU:C:2012:605); C-158/07. sz., Förster-ügyben hozott itélet (ECLI:EU:C:2008:630).

104 Lásd többek között a C-398/95. sz., SETTG-ügyben hozott itélet (ECLI:EU:C:1997:282) 23. pontját, illetve a C-109/04. sz., Kranermann-ügyben hozott ítélet (ECLI:EU:C:2005:187) 34. pontját.

105 Lásd különösen a C-158/07. sz., Förster-ügyben hozott ítéletet.

106 Lásd többek között a C-169/07. sz., Hartlauer-ügyben 2009 márciusában született ítéletet és annak jogirodalmi értékelését: „In the present political context of financial crisis the Court gave priority to social needs and underlined the freedom of Member States to organise their national systems as they wish, conditional upon respecting EU law." (NISTOR, Laura: Public Services and the European Union: Healthcare, Health Insurance and Education Services. Springer, The Hague, 2011.) 
irányból is jelentkeznek - elég csak a képesítések elismerésére vonatkozó uniós jogalkotásra és annak tagállami alkalmazási problémáira, a mobilitást ösztönző uniós források tagállami elosztásának szervezésére, a felsőoktatás „piacosításával” összefüggő kérdésekre vagy a mobilitás intenzitást közvetetten befolyásoló, fent vázolt magyarországi folyamatokra gondolnunk. Vitathatatlan tény, hogy a felsőoktatás európaizálódik, sőt globalizálódik, mind szervezési kereteit, mind pedig tartalmát tekintve, ennek útja viszont nem egyenletes. De miként folytatódik a történet? Vajon megtalálja-e Európa a felmerülő problémákra az adekvát válaszokat, hogy a Liszszaboni Stratégiában vizionált „tudásalapú európai társadalom és gazdaság” képe valóra válhasson? Vagy pedig a felsőoktatás is azon, feszültséggel terhelt területek sorát gyarapítja, ahol a nemzetállami keretek már nyilvánvalóan nem elegendőek, de az európai út még nem látszik tisztán.

\begin{abstract}
This article examines the jurisdiction of the Court of Justice of the European Union (CJEU) concerning the right of EU citizens to gain access to higher education in other EU Member States. The case-law plays an important intermediary role between various EU policies, often contributing to their more effective implementation in this way. The paper presents an obvious example for that as legal principles developed by the Court in free movement and anti-discrimination cases essentially facilitate the promotion of student mobility that is one of the fundamental objectives of the Bologna Process and the Union's education policy. At the same time, free student mobility may go against national education policies and interests and Member States are often reluctant to accept that the rulings, despite the limited competencies conferred upon the EU to take measures in the education sector, set narrow boundaries for national actions. The analysis also seeks to indicate those factors which have an influence on the Court's sensitivity towards interests and policy autonomy of the Member States in the field of higher education.
\end{abstract}

